\title{
TÖÖSTUSTÖÖLISTE TÖÖ- JA PUHKEAEG JA SELLE SEADUSANDLIK REGULEERIMINE EESTIS 1870-1940
}

\author{
Maie PIHLAMÄGI
}

Ajaloo Instituut, Rüütli 6, 10130 Tallinn, Eesti

Artiklis antakse ülevaade tööstustööliste tööpäeva pikkusest ja puhkeajast moodsa kapitalistliku tööstuse rajamise ja arengu ajajärgul Eestis ning käsitletakse neid tõukejõude, mis viisid tööaja lühenemisele 14-16 tunnilt 8 tunnile päevas (48 tundi nädalas) ning tasulise puhkuse sisseseadmisele.

\section{TÖÖPÄEV}

19. sajand tõi kõigi rahvaste materiaalsesse ellu ja tegevusse olulised muudatused, mille põhjusteks olid uute kaubaturgude avastamine, koloniaalpoliitika areng, rahvusvahelise kaubavahetuse tihenemine, tehnikaalased leiutised ja kapitalide kontsentreerumine tööstusse. Kõik see oli tihedalt seotud suurtööstuse rajamise ja arenguga. Industrialiseerimise käigus kerkisid väikeste töökodade asemele suured tehased ja vabrikud, mis koondasid sadu töölisi ning kus kasutati käsitsitöö asemel masinaid. Nende tööliste peamiseks elatusallikaks sai palgatöö. Masinate kasutamine muutis töö intensiivsemaks, sest koos tööstuse arenguga tekkis konkurentsivõitlus, milles jäid ellu vaid edukamad. Tööline pidi alluma nii masinate töö tempole kui ka ettevõtte vajadustele. Masin hoidis töölist pidevalt tegevuses, jätmata aega puhkuseks. Ettevõtetes valitsesid range töödistsipliin, 12-16-tunnine tööaeg ja madalad palgad, mis ei taganud töölisele äraelamist. Seetõttu pidid peale perekonnapea tihti nii naine kui ka lapsed tööle minema.

Kasumijaht jättis varju tootmise sotsiaalse külje: puudus huvi kasumitootjate ehk tööliste olukorra vastu. Põhjust tuleb otsida 19. sajandil domineerinud majanduslikust ja ühiskondlikust mõttest. 19. sajandi algul Adam Smithi rajatud majandusfilosoofiline koolkond propageeris vaba konkurentsi põhimõtet (laissez-faire). Ühiskonna teistes sfäärides väljendus see filosoofia individualismina. Sotsiaalalal eitas see valitsuse sekkumist töölisküsimusse ja oli igasuguse töölisseadusandluse vastane, sest see oleks piiranud tööstuslikku vabadust. 
Siiski oli ka teisitimõtlejaid, kes pidasid vajalikuks, et riigivõim sekkuks ja teeks lõpu ettevõtjate omavolile ning korrastaks ettevõtete omanike ja tööliste suhted. Eelkõige tunti muret füüsiliselt nõrkade, laste ja naiste olukorra pärast. Pikki tunde kestev monotoonne töö masinate taga tolmuses tööruumis, aga ka töötamine ööajal nõudis füüsilist pingutust ja mõjus kasvavale organismile nii vaimselt kui füüsiliselt hävitavalt. Selline töö kahjustas töölise tervist, ohutust ja ka arengut. Seetõttu olid tööõnnetused ja haigused igapäevane nähtus ning tööliste eluiga madal.

Sotsiaalseadusandlus ulatub tagasi 1802. aastasse, kui Inglismaal anti välja seadus alaealiste tööaja piiramiseks tekstiilitööstuses, kus kõige esmalt pandi alus kapitalistlikule suurtootmisele. Nii see kui ka järgmine, 1819. aasta seadus, mis seadis tööstuses töötamisele vanuselised piirid, jäid vaid paberile. ${ }^{1}$ Esimene seadus, mis lõpuks täies ulatuses ellu rakendati, oli 1833. aasta vabrikuseadus. Seetõttu peetakse 1836. aastat, mil seadus jõustus, töökaitse sünniaastaks. Seadus keelas alla 9-aastaste laste palkamise ja piiras 9-12-aastaste laste tööpäeva 8 tunniga ning 13-18-aastaste tööaja 12 tunniga päevas ja keelustas alla 18-aastaste öötöö tekstiilitööstuses. Seadus nägi ette anda lastele päevas vähemalt 2 tundi kooliharidust ja luua seaduse sätete täitmise kontrollimiseks vabrikuinspektsioon. ${ }^{2} 1840$. ja 1850. aastail järgnes rida seadusakte, mis lühendasid kõigi tööliste tööaega ja parandasid peamiselt laste ja naiste töötingimusi. Inglismaa eeskuju kandus ka teistesse Euroopa riikidesse, eelkõige Prantsusmaale ja Saksamaale.

Sotsiaalpoliitika arengule, mille aluseks oli algselt olnud ühiskondlik mõtteviis, andis tugeva tõuke töölisliikumine. Kui selle algusaegadel, 1840. aastail nõuti koguni kapitalistliku ühiskonna kõrvaldamist, siis hiljem pääses domineerima reformism, suund, mis jaatas sotsiaalset reformi. Sellele aitas kaasa kutseühingute liikumise tugevnemine. Ajapikku muutus sotsiaalreformide teostamine ja sotsiaalseadusandluse väljaarendamine sotsiaaldemokraatia peamiseks päevaülesandeks.

Venemaal, kus industrialiseerimine sai alguse pärast Krimmi sõda, kopeeriti esialgu Inglismaa industrialiseerimise mudelit ja ka sotsiaalpoliitikat, mis taotles alaealiste ja naiste töötingimuste parandamist vabrikutööstuses seadusandlikul teel. Nii nagu Tsaari-Venemaa tärkavas kapitalistlikus tööstuses tervikuna kasutati ka Eestis laialdaselt laste ja naiste tööjõudu. Nii oli 1858. aastal tegevust alustanud Narva Kreenholmi Puuvillamanufaktuuris naiste osatähtsus tööliste koguarvus (2000) $40 \%$ ja laste osatähtsus 20\%. Laste tööjõu tagas Kreenholmile leping Peterburi keiserliku kasvatusmajaga. ${ }^{3}$

1859. aastal moodustatud komisjon, kes tutvus Peterburi ja selle maakonna vabrikutes ja tehastes töötavate alaealiste töötingimustega, jõudis järeldusele, et karmid töötingimused mõjuvad hukutavalt nõrgale organismile, ning pidas vaja-

\footnotetext{
Hopkins, E. A Social History of the Working Classes 1815-1945. London, 1984, 55.

Samas, 59.

3 Герасимов В. Г. Жизнъ русского рабочего. Воспоминания. Москва, 1959, 19, 21; ЕАА, f 206, n 1, s 325, 14; s 188, 178.
} 
likuks kehtestada reeglid, mis seavad laste tööjõu kasutamisele vanuselised piirangud ning piiravad ka alaealiste tööaega. Peterburi linna ja makonna töösturid järgisid juba samal aastal omaalgatuslikult komisjoni soovitust. Rahandusministeeriumi juurde moodustati aga komisjon, kelle ülesanne oli täiendada vabriku- ja käsitööalaseid kehtivaid õigusakte alaealiste tööd reguleerivate sätetega. ${ }^{4}$ Komisjoni väljatöötatud projekt, mis nägi ette alla 12 -aastaste töö keelustamist vabrikutööstuses ja alaealiste tööpäeva piiramist 10 tunniga (koos vaheaegadega 12 tunniga) päevas, samuti kohustusliku koolihariduse andmist, valitsuse heakskiitu ei leidnud. Hiljem moodustati veel mitmeid valitsuse ja ka vabrikantide komisjone töökaitsealaste projektide väljatöötamiseks. Kõigi nende komisjonide töö lõppes 1882. aasta suvel alaealiste tööd vabrikutes ja tehastes käsitleva seaduse ${ }^{5}$ väljaandmisega. Seaduse väljatöötamisele avaldasid tugevat survet Peterburi töösturid, kes kasutasid laste tööd tagasihoidlikult, olles jõudnud arusaamisele, et täiskasvanute töö on laste tööst tunduvalt efektiivsem.

1. juuni 1882. aasta seadusega keelati alla 12-aastaste laste töö kasutamine vabrikutööstuses. 12-14-aastased lapsed tohtisid päevas töötada vaid 8 tundi (siia ei olnud arvestatud vaheaegu). Tööandja oli kohustatud andma neile vaheaja puhkamiseks ja einetamiseks pärast neli tundi kestnud töötamist. Laste töötamine ööajal (kella 9.00-st õhtul kuni 5.00-ni hommikul), nii nagu ka tervist kahjustavatel töödel, samuti pühapäevadel ja pühadel, oli keelatud. Ettevõtte omanikud olid kohustatud lubama neid alaealisi, kellel puudus vähemalt 1-klassilise rahvakooli lõputunnistus, kooli õppetööle kuni kolmeks tunniks päevas (18 tundi nädalas). Järelevalve teostamiseks seaduse sätete täitmise üle nähti ette luua uus institutsioon - vabrikuinspektsioon. Kuni seaduse jõustumiseni 1. mail 1884 oli teatud töödel lubatud erandkorras siiski kasutada ka 10-12-aastasi lapsi. ${ }^{6}$ Vaid poolteist kuud pärast seaduse jõustumist, 12. juunil 1884 nägi ilmavalgust uus seadus ${ }^{7}$ (jõustus 1. oktoobril), mis tegi 12-14-aastastele alaealistele kooliskäimise kohustuslikuks, kui neil puudus 1-klassilise rahvakooli lõputunnistus. Sellest johtuvalt lubas seadus 12-14-aastastel töötada järjest ilma vaheajata 6 tundi tingimusel, et töö ei kahjusta alaealise tervist ning et tema töötundide arv ööpäevas ei ületa 6 tundi. Juba järgmisel, 1885. aastal keelati vastava seadusega ${ }^{8}$ kõigi alla 17-aastaste alaealiste ja naiste töötamine ööajal tekstiilitööstuses. Tsaari-Venemaa koosseisu kuuluvas, kuid autonoomiat omavas Soomes võeti esimene alaealiste tööd reguleeriv õigusakt vastu alles 1889 . aastal. ${ }^{9}$

Enamiku vabrikutööliste tööaeg oli aga normeerimata ja kestis endiselt 12-14 tundi, hooajaliselt töötavates ettevõtetes (saeveskid, tsemendi-, lubja- ja tellise-

4 Литвинов-Фалинский В. П. Фабричное законодательство и фабричная инспекция в России. С.-Петербург, 1904, 21.

5 Полное Собрание Законов (ПСЗ) Российской империи. Т. II, 1882, Ст. 931.

6 Литвинов-Фалинский В. П. Фабричное законодательство и фабричная инспекция в России, 14.

7 ПСЗ. Т. IV, 1884, Ст. 2316.

8 ПСЗ. Т. V, 1885, Ст. 3013.

9 Vt Rahikainen, M. Children and "the right to factory work": Child labour legislation in nineteenthcentury Finland. - Scandinavian Economic History Review, 2001, 49, 1. 
tehased) koguni 15-16 tundi päevas. Venemaa ei erinenud sellest aspektist lähtudes oluliselt teistest maadest, sest 19. sajandil oli väga vähestes riikides kehtestatud seadusandlikul teel töötundide norm päevas (reeglina oli reguleeritud vaid laste tööaeg). Erandite hulka kuulus Prantsusmaa, kus 1848. aastal kehtestati 12-tunnise tööpäeva ülemmäär, Austrias ja Šveitsis oli tööstusettevõtetes kehtestatud tööpäeva maksimaalseks pikkuseks 11 tundi. ${ }^{10}$

Pikast tööpäevast tingitud üleväsimus põhjustas sageli tööõnnetusi ning palavad, umbsed ja tolmu täis tööruumid mõjusid halvasti töölise tervisele. Haiguskindlustus puudus, nii nagu ka töötus- ja pensionikindlustus. Järjest kasvav rahulolematus töötingimustega vallandus 1870 . aastail tööliste streikidena, mille käigus nõuti tööaja lühendamist. Esimeseks streigiks Venemaal, mil nõuti tööpäeva lühendamist, peetakse Narva Kreenholmi Puuvillamanufaktuuri tööliste 1872. aasta streiki. Streik lõppes edukalt: tööpäeva lühendati poole tunni võrra, 14 tunnilt 13,5 tunnile, ${ }^{11}$ laupäeviti lõpetati töö kaks tundi varem. Seega kehtis alates 1872. aastast Kreenholmi Manufaktuuris 79-tunnine töönädal.

1890. aastail, kui Venemaal algas tööstustõus, muutusid tööliste streigid, mil nõuti töötingimuste parandamist, eelkõige tööpäeva lühendamist ja palga tõstmist, massiliseks. Majandustõusu oludes lootsid töölised oma nõudmiste täitmist kergemini saavutada. Kõige aktiivsemalt nõudsid tööpäeva lühendamist 2 tunni võrra ja selle normeerimist seadusandlikult tekstiilitöölised, kelle tööpäev oli Venemaal üks pikemaid - kuni 14 tundi.

Tööaja normeerimist pooldas ka suur hulk tööstureid, sest aeg oli näidanud, et tööaja lühenedes kasvab tootlikkus. Eriti olid sellest huvitatud Peterburi ja Łódźi tööstuspiirkonnas tegutsevate ettevõtete omanikud, kes, praktiseerides ühe vahetusega tööd, tunnetasid peamiste konkurentide - Moskva ettevõtete eelist, mille andis neile töötamine kahes vahetuses (18 tundi päevas, vahetus 9 tundi). Peterburi töösturid soovisid tööaja üldiseks riiklikuks maksimaalseks normiks kehtestada 12 tundi päevas, et võrdsustada konkurentsitingimused. ${ }^{12}$ Kuna tööaja reguleerimist käsitleva seaduseelnõu väljatöötamiseks moodustatud valitsuskomisjoni välja pakutud 11-tunnine tööpäev ei rahuldanud kumbagi töösturite gruppi, jõuti kompromissile. Ühises märgukirjas valitsusele teatati, et tööaja lühendamine alla 11,5 tunni päevas ei vasta Venemaa tööstuse kandejōule, hakates takistama tööstuse arengut. ${ }^{13}$ Töösturite seisukoht võeti arvesse.

2. juuni 1897. aasta seadusega tööaja pikkusest ja jaotusest vabrikutööstuses ${ }^{14}$ kehtestati vabrikutes ja tehastes kuuepäevane töönädal. Maksimaalseks töötundide arvuks päevas ühe vahetusega töötamisel määrati 11,5 tundi ja pühade-eelsetel päevadel, laupäevadel ning öötööl 10 tundi. Ööajaks peeti ühes vahetuses töötamisel aega kella 9.00-st õhtul kuni kella 5.00-ni hommikul ning kahe ja enama

\footnotetext{
10 Rebane, I. Sotsiaalpoliitika ja töökaitse. Tartu, 1939, 76.

11 Vassar, A. Töölisliikumise esimesed sammud Eestis. Tallinn, 1954, 73.

12 Литвинов-Фалинский В. П. Фабричное законодательство и фабричная инспекция в России, 30.

13 Лаверычев В. Я. Царизм и рабочий вопрос в России (1861-1917 гг.). Москва, 1972, 95.

14 Собрание узаконений и распоряжений правительства, 1897, Ст. 778.
} 
vahetusega töötamisel aega kella 10.00-st õhtul kuni kella 4.00-ni hommikul. Öötöö ${ }^{15}$ oli lubatud kõigis tootmisharudes.

Kahe vahetusega 18 tundi töötavates ettevõtetes lubati tööpäeva pikendada 12 tunnini, kusjuures tuli kinni pidada kahe teineteisele järgneva nädala tööaja kestusest, mis piirati 108 tunniga. Katkematu tööprotsessi korral tuli töölise igapäevase tööaja kestus kindlaks määrata töögraafikuga, pidades kinni kahe teineteisele järgneva ööpäeva tööaja kestusest, mis ei tohtinud ületada 24 tundi, ühest vahetusest teise ülemineku puhul 30 tundi.

Peale tööaja üldise normi nägi seadus ette ka võimaluse rakendada ületunnitööd ning kehtestas kohustuslikud puhkepäevad. Seadus jõustus 1. jaanuarist 1898. aastal. Järelevalve seaduse täitmise üle oli vabrikuinspektsiooni ülesanne. Seaduse sätete rikkumise korral ootas ettevõtjaid rahatrahv.

2. juuni 1897. aasta seadusega kehtestati esmakordselt tööstustööliste (alates 15. eluaastast) tööaja riiklik maksimaalne norm 11,5 tundi päevas ehk 67,5 tundi nädalas ning puhkeaja kestus. Noorukid alates 15 . eluaastast olid võrdsustatud täiskasvanutega, sest lühendatud tööpäeva rakendamist nende suhtes seadus ette ei näinud. Kuigi tööpäev jäi suhteliselt pikaks, tuleb seaduse tähtsust näha eelkõige selles, et see tegi lõpu tööaja sõltuvusele ettevõtte omaniku tahtest ja suurendas tööliste puhkeaega. Tööliste majandusliku olukorra aspektist vaadatuna oli oluline, et tööaja lühenemisega kaasnes palgatõus, mida võimaldas tööstuse kiire kasv 19. sajandi 90. aastail.

Igas ettevõttes määrati vabrikuinspektori poolt kinnitatud ettevõtte juhatuse koostatud sisekorraeeskirjadega kindlaks tööajakorraldus, s.o tööaja algus ja lõpp, puhkuseks ja einetamiseks antav vaheaeg, samuti muud tööpäevasisesed vaheajad ning ühest vahetusest teise ülemineku aeg ja kord, samuti puhkepäevad. ${ }^{16}$

Uut seadust ellu rakendades seadsid Eestimaa kubermangu juhtiva tööstusharu - tekstiilitööstuse vabrikandid ettevõtetes sisse tööpäeva piirnormi, mis enamikule nende ettevõtete töölistest tähendas tööpäeva lühenemist 1,5-2 tunni võrra. Koos Peterburi tekstiilitöölistega 1896. aasta lõpul ja 1897. aasta algul aktiivselt tööpäeva lühendamise eest võidelnud Eestimaa suurima tööstusettevõtte - Kreenholmi Manufaktuuri osaühingu juhatus otsustas seaduse väljaandmist ära ootamata tööliste nõudmisele vastu tulla ja töörahu huvides lühendada ettevõttes alates 21. aprillist 1897 tööpäeva kahe tunni võrra - 13,5 tunnilt 11,5 tunnile, laupäeval 10 tunnile, seega töötundide arvu nädalas $79-1 t$ 67,5-le. ${ }^{17}$ Koos tööpäeva lühendamisega tõsteti ka päevapalka ja tükitööhindu 10-15\%, et töölised ei kaotaks tööaja lühenemise tõttu palgas. ${ }^{18}$ Ka paberi-, puidu-, keemia- ja mineraalainete

15 Erandina oli keelatud naisi ning 15- ja 16-aastasi noorukeid rakendada tööle ööajal (ajavahemikus kella 9.00-st õhtul kuni kella 5.00-ni hommikul) tekstiilitööstuses. 12-14-aastaste öötöö oli keelustatud kõigis tootmisharudes, välja arvatud klaasitööstuses tingimusel, et 6-tunnisele tööajale järgneb vähemalt 12-tunnine puhkeaeg (vt ПС3. Т. X, 1890. Ст. 6742).

16 Vabrikuinspektsiooni institutsioon laienes Eestimaa ja Liivimaa kubermangule 1894. aastal, enne seda kontrollis Peterburi vabrikuinspektsioon nende kubermangude tööstusettevõtteis vaid alaealiste tööseadusandluse täitmist.

17 Eesti Ajalooarhiiv (EAA), f 206, n 1, s 189, 1 106, 107.

18 EAA, f 206, n 1, s 189, 1116. 
töötlemise tööstuse ettevõtetes seati sisse 11,5-tunnine tööpäev. Nende tootmisharude töölistel lühenes tööpäev senisega võrreldes poole tunni võrra. Ainult üksikutes suuremates ettevõtetes kehtestati veelgi lühem tööpäev: Waldhofi tselluloosivabrikus 10-tunnine, A. M. Lutheri mehaanilises puidutöötlemise vabrikus ja A. Mohri mööblivabrikus 11-tunnine. ${ }^{19}$ Metallitööstuse suurettevõtetes, nagu F. Wiegandi, Volta ja Fr. Krulli masinatehases, kehtestati 11-tunnine, Dvigateli vagunitehases aga 10,5-tunnine tööpäev. ${ }^{20}$ Väiksemates metallitööstuse ettevõtetes, näiteks J. Haubneri tehases Tartus ja Ernst \& Ko mehaanikatehases Tallinnas, pandi endise 12-tunnise asemel maksma 11,5-tunnine tööpäev. ${ }^{21}$

Ka pärast seaduse elluviimist säilisid endiselt erinevused tööpäeva pikkuses nii tööstusharude kui ka ühe tööstusharu üksikute ettevõtete piires ja seda mitte ainult Eestimaa ja Liivimaa kubermangus, vaid Venemaa vabrikutööstuses tervikuna. Kõige rohkem võitsid selle seadusega tekstiilitöölised. Tööpäeva pikkus eri tootmisharudes sõltus ettevõtte tehnilisest ja tootmistasemest, tootmise korraldamisest, tööliste kvalifikatsioonist, samuti sellest, kuidas töölised suutsid oma töötingimuste parandamise eest võidelda ja millisel määral nõustusid ettevõtjad tööliste nõudmisi täitma. 20. sajandi alguseks kujunes Venemaa töötlevas tööstuses tööpäeva keskmiseks pikkuseks 10,6 tundi. ${ }^{22}$ Venemaa tööstustööliste tööpäev oli vaid veidi pikem kui Saksamaal, kus see oli keskmiselt 10,5 tundi. Inglise tööliste keskmine tööpäeva pikkus oli aga selleks ajaks lühenenud peaaegu 9 tunnini.

Venemaa töölisklass jätkas võitlust tööpäeva lühendamise eest 1905. aastal puhkenud revolutsiooni päevil. Eesti tööstusettevõtete töölised nõudsid 10-tunnist tööpäeva, ehkki VSDTP Tallinna Komitee kutsus oma lendlehes 1905. aasta jaanuaris töölisi üles võitlema 8-tunnise tööpäeva kehtestamise eest "nagu meie vennad Piiteris". ${ }^{23}$ Sellise pikkusega tööpäev ei olnud tolleaegse Euroopa tööstusriikideski reaalne, rääkimata tööstuslikult mahajäänud Venemaast. Tallinna, Narva ja Tartu tööliste 1905. aasta kevadel ja sügisel toimunud üldstreikide tulemusena olid ettevõtjad sunnitud lühendama tööpäeva, vähendama ületunnitööd, tõstma palka ning parandama teisi töötingimusi.

Kokkuvõtte tööpäeva lühenemise kohta tööstusettevõtetes tegi Eestimaa kubermangu vabrikuinspektor 1906. aasta juunis. Sellest selgus, et suuremates tekstiilitööstuse ettevõtetes - Narva Kreenholmi Puuvillamanufaktuuris ja Balti Puuvilla Ketramise ja Kudumise Vabrikus lühenes tööpäev streigivõitluse tagajärjel 11,5 tunnilt 10,5 tunnile (töönädal 61,5 tunnile), ülejäänud tekstiilitööstustes kehtis endiselt 11,5-tunnine tööpäev (töönädal 67 tundi). Paberi-, puidu- ja keemiavabrikuis oli tööaeg vabrikuinspektori andmetel lühenenud 11,5 tunnilt 10 tunnile (töönädal 59 tunnile), metalli- ja masinatehastes 11,5-11 tunnilt 10 tunnile,

19 EAA, f 206, n 1, s 168, 1 26; f 559, n 2, s 27, 1 189, 361; f 560, n 1, s 49, 12.

20 EAA, f 208, n 1, s 47, 1 182; s 49, 12, 3; f 206, n 1, s 218, 173; f 209, n 1, s 50, 111.

21 EAA, f 560, n 1, s 102, 14; f 290, n 1, s 49, 11.

22 Кирьянов Ю. И. Жизненный уровень рабочих России (конец XIX-начало XX в.). Москва, $1979,48$.

23 EAA, f 206, n 1, s 148, 19. 
Dvigateli vagunitehases 9 tunnile. ${ }^{24}$ Mineraalainete töötlemise tööstuse ettevõtetes (tsemendi-, tellise- ja lubjatehased) tööaeg ei muutunud, endiselt jäi kehtima 11,5-tunnine tööpäev. ${ }^{25}$ Kuna selles tööstusharus töötati enamasti hooajaliselt, siis peeti pikemat tööpäeva täiesti loomulikuks, võrreldes nende tööstusettevõtetega, kus tootmisprotsess toimus aastaringselt.

Kogu Venemaa töötlevas tööstuses lühenes keskmine tööpäev 10,6 tunnilt 1904. aastal 10,2 tunnile 1905. aastal. ${ }^{26}$ Soomes oli 1905. aasta üldstreigil tööliste tööpäeva lühenemisele samuti oluline tähtsus. 1884. aastal oli enamikus ettevõtetest 12-tunnine ja ainult vähestes 10-11-tunnine tööpäev. 1905. aasta üldstreik tõi endaga kaasa tööpäeva lühenemise peaaegu pooltes ettevõtetes 9,5-10 tunnini (töönädal 57-60 tundi) ning ligi kolmandikus ettevõtetes 8-9,5 tunnini (töönädal 48-57 tundi). ${ }^{27}$ Nii oli töölisklassi üks peamisi võite 1905. aasta revolutsioonis palgatõusu kõrval tööpäeva lühenemine keskmiselt ühe tunni võrra.

Revolutsioonipäevil kerkis päevakorda ka tööpäeva lühendamine seadusandlikus korras. Juba jaanuaris 1905 asus valitsus aktiivselt töölisküsimusega tegelema. Ministrite Nõukogus vaadati läbi tööseadusandluse edasise täiustamise põhisuunad, nende hulgas tööaja lühendamine. Seadusprojekte välja töötanud komisjonide seisukohad olid tööaja suhtes erinevad. Üks 1905. aasta veebruaris valminud projekte piiras tööaja ühe vahetusega töötamise puhul 10, kahe vahetusega töötamise puhul 9 ja kolme vahetusega töötamise puhul 8 tunniga. 1906. aasta aprillis välja töötatud variant nägi ette tööaja piiramist 10,5 tunniga päevas. ${ }^{28}$ Järgnevatel aastatel - revolutsiooni taandumise ja töölisliikumise languse perioodil - ei pidanud valitsus enam vajalikuks tööseadusandluse täiustamisega aktiivselt tegelda. Seni väljatöötatud seaduse projektid tööaja, haiguskindlustuse jt valdkondade kohta pandi kalevi alla.

1910. aastal alanud tööstusliku tõusu aastail nõudsid töölised taas jõuliselt tööpäeva lühendamist. Tugevneva töölisliikumise survel andis valitsus KaubandusTööstusministeeriumile ülesande töötada välja seaduse projekt tööaja normeerimise kohta. Ettevalmistustöö käigus kogus Kaubandus-Tööstusministeerium 1913. aastal andmeid tööpäeva pikkuse kohta vabrikutööstuses. Tulemused näitasid, et 1913. aasta 1. novembri seisuga oli keskmine tööpäeva pikkus Venemaa vabrikutööstuses 9,9 tundi, kusjuures arvesse ei olnud võetud tööaega laupäevadel, pühade-eelsetel päevadel ning ületunde. ${ }^{29}$ Aasta lõpuks oli ministeeriumil välja töötatud seaduse projekt, mille kohaselt naiste ja noorukite (15- ja 16-aastaste) tööaega piirati 10,5 tunniga, laste (12-14-aastaste) tööaega 6 tunniga päevas ning

24 Центральный Государственный Исторический Архив России (ЦГИАР), ф. 23, оп. 20, д. 45, л. 13-14.

25 EAA, f 206, n 1, s 154, 1 88; s 156, 1 7; f 208, n 1, s 87, 138.

26 Кирьянов Ю. И. Жизненный уровень рабочих, 55.

27 Suomen taloushistoria. 2. Teollistuva Suomi. Helsinki, 1982, 152. Soomes, Vene impeeriumi autonoomses üksuses 1897. aasta 2. juuni seadus tööpäeva pikkuse kohta ei kehtinud.

28 Съезды Представителей Промышленности. Материалы по рабочему вопросу, 1906, 1, 11.

29 Кирьянов Ю. И. Жизненный уровень рабочих, 48. 
keelati nende öötöö (kella 9.00-st õhtul kuni 9.00-ni hommikul). ${ }^{30}$ Ülejäänud tööliste tööaja normeerimist projekt ei käsitlenud.

Valitsus ei rutanud Riigiduumale esitama 1897. aasta seaduse muudatusettepanekuid, mis oleksid tööaega lühendanud. 1913. aastal avaldatud "Tööstusliku töö seadustik",31 ("Устав о промышленном труде") kodifitseeris vaid kehtiva vabrikuseadusandluse, sealhulgas tööliste töö- ja puhkeaega käsitlevad õigusaktid. Nii jäi tööaeg ettevõtteis endiseks kuni Esimese maailmasõjani. Sõja-aastail vähenes töötundide arv nii päevas kui ka nädala kokkuvõttes neis ettevõtteis, kes olid sunnitud oma tootmist kokku tõmbama. See muudatus fikseeriti ka ettevõtte sisekorraeeskirjas. Nii näiteks kehtestati Räpina paberivabrikus seoses tootmise vähenemisega tööpäeva pikkuseks endise 11 tunni ja 15 minuti asemel 10 tundi 15 minutit. $^{32}$

Uue hooga puhkes võitlus tööpäeva lühendamise eest Veebruarirevolutsiooni päevil. Seekord nõuti aga juba 8-tunnise tööpäeva sisseseadmist. ${ }^{33}$ Kõigi suuremate ettevõtete töölised selle ka saavutasid. Seadusandlikult kehtestas 8-tunnise tööpäeva Nõukogude valitsus 1917. aasta 29. oktoobri dekreediga. ${ }^{34}$ Saksa okupatsiooni ajal pikendati taas Eesti tööstusettevõtetes tööaega, et sõja võitmiseks oleks tagatud sakslaste varustamine vajalikuga.

Vahetult pärast Saksa okupatsiooni lõppu, 16. detsembril 1918 deklareeris Eesti Ajutine Valitsus pöördumises Eesti Vabariigi kodanike poole, et 8-tunnine tööpäev tööstuses ja kaubanduses hakkab uuesti maksma. ${ }^{35}$ Ühtki tööaega käsitlevat õigusakti, mis oleks 8-tunnise tööpäeva Eestis seadustanud, ei järgnenud. Samuti ei tunnustatud 29. oktoobri dekreeti, sest 19. novembri 1918. aasta "Ajutised administratiivseadused" panid Eestis Vabariigis maksma kõik need Vene õigusaktid, mis olid jõus enne bolševistlikku riigipööret 24. oktoobril $1917 .^{36}$ Seega oli jõus ka tööstusliku töö seadustik, milles oli fikseeritud tööaja maksimaalne norm - 11,5 tundi päevas.

Rahvusvahelises ulatuses tunnustati ametlikult 8-tunnist tööpäeva ja 48-tunnist töönädalat tööstuses Rahvusvahelise Tööorganisatsiooni 1919. aasta konventsiooni "Töötunnid tööstuses" ${ }^{37}$ alusel.

30 Rahvaleht, 1913, 14. dets.

31 Устав о промышленном труде. Свод законов Российской империи, 1913. Т. ХІ, ч. 2.

32 EAA, f 560, n 1, s 59, $120,118$.

33 Saksa ja prantsuse sotsialistide eeskujul oli nii III kui ka IV Riigiduuma sotsiaaldemokraatlik fraktsioon esitanud duumale heakskiitmiseks seaduseelnõu 8-tunnise tööpäeva kehtestamise kohta Venemaa vabrikutööstuses, kuid see lükati tagasi.

Riigi Teataja (RT), 1918, 1, 4.

Riigi Teataja, 1918, 1, 7.

37 Hours of Work (Industry) Convention, 1919. - http://www.ilo.org/ilolex/cgi-lex/convde.pl?C001. 8-tunnise tööpäeva nõudmise püstitas Robert Owen juba 1817. aastal. Tema nõudmist kordasid hiljem kutseühingud Inglismaal ja mujal, kuigi nad ei suutnud saavutada nõudmise elluviimist. 1. mail 1890. aastal toimusid 8-tunnise tööpäeva toetuseks võimsad meeleavaldused. Üksikud tööandjad teostasid 8-tunnise tööpäeva omaalgatuslikult, minnes üle kolmes vahetuses töötamisele, sest pidasid lühikest tööaega sotsiaalselt kasulikuks: kasvas töö tootlikkus, sest töölistel oli tööjõu taastootmiseks piisavalt puhkeaega. 
Erinevalt mitmest maailma (Tšiili, India, Pakistan) ja Euroopa riigist (Kreeka, Rumeenia, Austria, Itaalia, Belgia, Bulgaaria, Läti, Prantsusmaa, Luksemburg, Portugal, Hispaania, Leedu), kes ratifitseerisid 8-tunnise tööpäeva konventsiooni, Eesti sellega ei ühinenud, järgides maailma tähtsamate tööstusriikide Ameerika Ühendriikide ja Suurbritannia ning naaberriigi Soome eeskuju. Vaikival kokkuleppel kehtis Eestis edasi 8-tunnine tööpäev ning sellele aitasid kaasa töökaitsekomissarid (endised vabrikuinspektorid, alates 1927. aastast tööinspektorid). Reeglina jätsid töökaitsekomissarid kinnitamata nende ettevõtete sisekorraeeskirjad, mis sätestasid pikema tööpäeva kui 8 tundi, ja soovitasid pikema töötamise vajaduse korvata ületunnitööga kokkuleppel töölistega. ${ }^{38}$ Sellest aga polnud töösturid huvitatud, sest ületunnitöö eest tuli maksta kõrgemate tariifide alusel. Kuna töösturite karistamiseks puudus seaduslik alus, praktiseeriti osas ettevõtetest ikkagi 10-tunnist tööaega, viidates kehtivale tsaariaegsele tööstusliku töö seadustikule. Töökaitsekomissarid avastasid kontrollkäikude ajal ettevõtetesse 1923. aastal 69, 1924. aastal 42, 1925. aastal 77 ja 1926. aastal 68 tööaja jaotust ja kestust puudutavat kõrvalekaldumist. ${ }^{39}$ Õiguslik vaakum tingis selle, et tööaeg oli siiski sõltuvuses ettevõtja tahtest.

Sotsiaaldemokraatide arvates oli riiklikult tööaega normeeriva seaduse puudumine kaudselt sü̈̈di ka tööpuuduses, sest juhul, kui oli vaja tootmist suurendada, pikendati tööaega, selle asemel et palgata uusi töölisi. 1925. aastal avaldas sotsiaal-poliitilise ajakirja Töö ja Tervis toimetaja Leopold Johanson ajakirjas artikli tööpäeva pikkusest ja tööaja jaotusest tööstusettevõtetes, millega ta soovis avalikkust probleemidest informeerida ja tegemata jätmiste pärast valitsuse südametunnistusele koputada. Ta märkis, et 8-tunnist tööpäeva tunnustatakse ainult ühes osas tööstustes, teistes mitte, ning et ületunnitöö on muutunud igapäevaseks nähtuseks ja seda tehakse sageli ilma töökaitsekomissari loata. Ületunde tehakse ajal, kui töölisi lahti lastakse või töötatakse ainult 3-5 päeva nädalas. Töövaheajad on pea täiesti kadunud: mõnel pool töötatakse isegi kuni 12 tundi järgemööda. Võrrelnud Eesti olukorda kultuurmaadega, jõudis autor järeldusele, et Eesti tööstuses alavääristatakse töölist, kelle olukord on muutunud väljakannatamatuks pika tööpäeva ja väikese palga tõttu ning see on nii rahva tervishoiu seisukohalt kui ka riiklikult lubamatu. ${ }^{40}$

1925. aastal esmakordselt avaldatud andmed tööpäeva pikkuse kohta tööstusharude kaupa näitasid, et kõige pikem tööpäev - 8,8 tundi - oli paberitööstuses. Järgnesid puidutööstus ja kaevandused 8,6-tunnise tööpäevaga. Keemiatööstuses oli keskmiseks tööpäeva pikkuseks 8,3 tundi ja tekstiilitööstuses 8,1 tundi. Ainuke tootmisharu, kus tööpäev oli 8 tunnist lühem, oli trükitööstus (7,9 tundi). ${ }^{41}$ Tervikuna oli tööpäeva keskmine pikkus suurtööstuses 1924. aastal 8,35 tundi,

38 ERA, f 2113, n 3, s 153, 165.

39 Sõrmus, R. Töökaitse 1921-26. - Eesti Statistika, 1927, 700.

40 Johanson, L. Tööpäeva pikkus, ületunnitööd, töövaheajad ja tööviljakus. - Töö ja Tervis, 1925, 2,120 .

41 Töötingimused suurtööstuses 1925. a esimesel poolel. - Eesti Statistika, 1925, 41, 44. 
1925. aastal 8,39 tundi, 1927. aastal 8,31 tundi ja 1928. aastal 8,42 tundi. $^{42}$ Arvesse on võetud 16-aastaste ja vanemate tööstustööliste tööaeg, sest 1924. aasta seadusega laste, alaealiste ja naiste tööaja kohta tööstusettevõtetes ${ }^{43}$, mis valmis Rahvusvahelise Tööorganisatsiooni vastavate konventsioonide alusel, oli alla 14-aastaste töö tööstusettevõtetes keelatud. 14-15-aastased koolikohustuslikud lapsed võisid töötada vaid koolivaheajal maakonna või linna koolivalitsuse loal. Nende tööaeg oli piiratud 6,5 tunniga, tekstiilitööstuses aga 6 tunniga päevas, ületunnitöö ja töötamine pühapäevadel ja pühadel oli keelatud. Samuti sätestas seadus tervisekahjulikud tööd, kus alla 18-aastaste kasutamine ei olnud lubatud. Alla 18-aastaste ja naiste öötöö oli kõigis tööstusettevõtteis keelatud. See säte oli täiesti uus, sest tsaariajal oli alaealiste ja naiste öötöö keelatud vaid tekstiilitööstuses. Naiste osatähtsus töötajate üldarvus (42 300) oli küllalt suur, moodustades 1923. aastal ligi kolmandiku -31,4\%. Alaealiste osatähtsus oli 1,5\%. Pea pool naistöölistest leidis rakendust tekstiilitööstuses, alaealistest üle poole töötas kahes tööstusharus - metalli- ja tekstiilitööstuses. ${ }^{44}$

Ülemaailmsest majanduskriisist tingitud maailmaturu konjunktuuri halvenemise tõttu tuli tootmist kokku tõmmata ja seetõttu vähenes töötundide arv nii päevas kui ka nädalas. Tööhõive tagamiseks esitasid sotsiaaldemokraadid 1929. aastal Riigikogule eelnõu, mis aga menetlusest välja hääletati. Alles 1931. aastal esitas valitsus parlamendile heakskiitmiseks tööstuslike käitiste tööaja seaduse eelnõu, mis oli valminud Sotsiaalministeeriumis ning mille eeskujuks olid võetud Rahvusvahelise Tööorganisatsiooni 1919. aasta 8-tunnise tööpäeva konventsiooni sätted. ${ }^{45}$

Riigikogus 10. juulil 1931. aastal heaks kiidetud "Tööstuslikkude käitiste tööaja seadus" ${ }^{\$ 6}$ (jõustus 1. septembril) kehtestas, et tööstustöölise tööaeg ei tohi olla pikem kui 8 tundi ööpäevas ja 48 tundi nädalas. Kõigile tööstustele oli kohustuslik fikseerida tööpäeva pikkus sisekorraeeskirjades või töölise palgaraamatus. Samuti määrati kindlaks sanktsioonid, mille alusel oli seadust rikkunud ettevõtjaid võimalik vastutusele võtta.

Seadus nägi ette ka erandid, millal võis tööaeg tööstusettevõtteis olla pikem kui 8 tundi. Tööaeg võis ulatuda 168 tunnini kolme üksteisele järgneva nädala jooksul katkematu tööprotsessiga ettevõtteis, mille nimekirja kinnitas valitsus. Tööaega võis pikendada ühe tunni võrra hädatööde juhtudel ettevõtte juhatusest olenematutel ja ettenägematutel põhjustel tekkinud tööseisakute tagajärjel kaotatud aja tagasivõitmiseks, kuid seda ainult tööliste nõusolekul ja tööinspektori teadmisel.

42 Sõrmus, R. Tööpäeva pikkus tööstuses 1927. a. - Eesti Statistika, 1928, 82, 543; Sõrmus, R. Tööpäeva pikkus tööstuses 1929. aastal. - Eesti Statistika, 1930, 107, 533.

43 Riigi Teataja, 1924, 68, 30.

44 Töökaitse Eestis 1927. a. Tööinspektorite 1927. a aruannete kokkuvõtt. Tallinn, 1928, 14-15.

45 Seletuskiri tööstuslikkude käitiste tööaja seaduse juurde. IV Riigikogu täielikud protokollid, 7. istungjärk 1931, prot nr 139-169, lisad, lk 562.

46 Riigi Teataja, 1931, 61, 487. 
Tööandja oli kohustatud andma töötajale vaheaja puhkamiseks ja einetamiseks kestusega 0,5 tunnist 1,5 tunnini pärast viis tundi kestnud töötamist. Juhul kui tööpäev oli lühem kui 8 tundi või töötamine toimus kolmes vahetuses, polnud vaheaja andmine kohustuslik, kuid töölisel pidi olema võimalus töö ajal süüa.

Lubatud oli töötada ka üle kehtestatud tööajanormi ehk teha ületunnitööd, kuid selle mahtu vähendati seni kehtinud 120 tunnilt 75 tunnile aastas ühe töölise kohta. Seaduse täitmise järelevalve lasus tööinspektsioonil. Seaduse sätete rikkumise eest võis ettevõtte omanikku karistada rahatrahviga kuni 500 krooni ulatuses või kuni kolmekuulise arestiga.

Töösturite jaoks tööaja riikliku normi -8 tundi päevas - kehtestamine eriti valulik polnud, sest kriisiaastail oli tootmise kokkutõmbamise tagajärjel töötatud paljudes tööstustes niigi lühendatud tööpäeva ja töönädalaga. Statistilised andmed näitasid, et töötundide arv suurtööstuses, võrreldes 1928. aastaga, kui tehti kokku 64,6 mln töötundi, oli 1931. aastaks vähenenud 53,2 mln töötunnini (kahanemine 17,6\%). 1932. aastal oli tööaeg $46 \mathrm{mln}$ tundi, seega $28,8 \%$ lühem kui 1928. aastal. 1932. aasta esimesel poolaastal oli tööpäeva keskmine pikkus suurtööstuses esmakordselt alla 8 tunni. ${ }^{47}$ Nii seadustas 1931. aasta seadus tegelikult olukorra, mis oli Eestis tööstuses kriisiaastail välja kujunenud. Tööaja piiramisega 8 tunniga ja ületunnitöö mahu vähendamisega taotleti tööhõive suurendamist, sest juhul kui tekkis vajadus tootmist suurendada, tuli palgata lisatööjõudu.

Seaduse rakendamisel ei olnud siiski alati positiivsed tagajärjed. Neis ettevõtteis, kus kehtis lühem töönädal, pikendati see 48 tunnile, suurendades töötundide arvu laupäeval. Selliste ettevõtete hulka kuulus ka Kreenholmi Manufaktuur, kus hoolimata tööliste protestist kehtestati 30. jaanuarist 1932 laupäevadel 6-tunnise tööaja asemel 8-tunnine, mille tõttu pikenes nädalane tööaeg 1917. aasta märtsist kehtinud 46 tunnilt 48 tunnile. ${ }^{48}$ Töölistel tuli tööaja pikenemisega leppida, sest kriisiolukorras oli uue töökoha leidmine pea võimatu. Alles 1936. aasta mais taastati Kreenholmi Manufaktuuris tööliste streigi ähvardusel 46-tunnine töönädal. ${ }^{49}$

1930. aastate teise poole tööstusliku elavnemise ja tõusu aastail alustasid töösturid tööaja seaduse vastu aktiivselt rünnakut, avaldades survet 8-tunnise tööaja normi tühistamiseks. Seaduse muudatusega sooviti eelkõige kehtestada pikemat tööaega sesoonsetes tootmisharudes. ${ }^{50}$ Ületunnitöö osas tehti hooajaliselt töötavates tööstusharudes küll mööndusi, kuid tööstuses jäi kehtima tööaja üldine riiklik norm -8 tundi päevas (48 tundi nädalas).

Rahvusvahelises ulatuses toimus aga 1930. aastail võitlus juba 40-tunnise töönädala eest. Rahvusvaheline töökonverents asus 1935. aastal 40-tunnise töönädala suhtes pooldavale seisukohale. Selles nähti vahendit vähendada areneva ratsionaliseerimise tagajärjel tekkinud tööpuudust ja kindlustada töölistele osasaamist

47 Sõrmus, R. Tööpäeva pikkus tööstuses 1932. a. - Eesti Statistika, 1933, 139, 314, 316.

48 Kreenholmi Puuvillasaaduste Manufaktuuri Osaühisus 75. 1857-1932. Tallinn, 1933, 75; Eesti Riigiarhiiv (ERA), f 2113, n 1, s 245, 115.

49

ERA, f 2113, n 1, s 372, 174 .

50 ERA, f 50, n 1, s 2583, 1 139-141. 
kasvavaist kultuurivaradest. Samuti leiti, et töö tootlikkus on sel määral kasvanud, et see õigustaks tööaja lühendamist. ${ }^{51}$ 40-tunnise töönädala põhimõte leidis toetust Ameerika Ühendriikides, Prantsusmaal, Uus-Meremaal, Belgias, Tšehhoslovakkias, Itaalias ja mujal. Nõukogude Liidus kehtis koguni viiepäevane töönädal ja 7-tunnine tööpäev. ${ }^{52}$

\section{ÜLETUNNITÖÖ}

Hoolimata sellest, et vabrikutööliste tööpäev oli 19. sajandil ülemäära pikk, rakendati neis ettevõtteis ületunnitööd, et korvata tööaega, mida oli lühendatud kas ettevõtjate omaalgatusel või tööliste nõudmisel. Üks selliseid tootmisharusid oli alates 1870. aastatest kiiresti arenenud masina- ja metallitööstus, kus tööpäeva keskmine pikkus oli 11-11,5 tundi. Nii näiteks tehti E. Lausmanni (100 töölist) ja F. Wiegandi (350 töölist) masinatehastes 1896. aasta mais ja juunis ületunnitööd, millega oli kummaski ettevõttes hõivatud $25 \%$ töölistest. ${ }^{53}$ Töölised tegid meelsasti ületunnitööd, sest tasu maksti kõrgendatud palgatariifide alusel. Nii näiteks tasuti F. Wiegandi masinatehases esimese ületunni eest tariifi alusel, mis moodustas $12,5 \%$ päevapalgast, teise ületunni tasu oli juba $25 \%$ päevapalgast jne. Iga järgmise ületunni eest suurenes ka tasumäär. ${ }^{54}$ Põhjalik analüüs näitas aga, et rohke ületunnitöö praktiseerimine ei toonud ettevõttele kaasa loodetud kasu, sest tööliste üleväsimuse tõttu sagenesid ka tööluusid. E. Lausmanni tehases tuli tavaliselt 11-tunnise tööpäeva jooksul ühe töölise kohta 0,3 tundi tööluusi (hilinemine, ajutiselt tööpostilt lahkumine), ületunnitööd rakendades aga 0,7 tundi. F. Wiegandi masinatehases olid vastavad näitajad 0,8 ja 1,2 tundi. $^{55}$

Järelikult polnud mõistlik niigi pika tööpäeva puhul nõuda töölistelt ületundide tegemist, kui see just hädavajalikuks ei osutunud. Seetõttu toetasid ka töösturid 2. juuni 1897. aasta seaduse "Tööaja pikkusest ja jaotusest vabrikutööstuses" sätet, mis piiras töölise ja tööandja kokkuleppel rakendatavat ületunnitööd (vabatahtlikku ületunnitööd) ehk töötamist sel ajal, kui sisekorraeeskirjade järgi ei olnud ette nähtud töötada 120 tundi töölise kohta aastas. Vabatahtliku ületunnitöö tegemiseks tuli ettevõtte administratsioonil taotleda luba vabriku- ja mäeasjade komisjonilt. Ületunnitöö, mida tööline oli kohustatud täitma vääramatu jõu korral, ei olnud piiratud. Kohustusliku ületunnitöö tingimused tuli fikseerida töölise palgaraamatus (töölepingus). Mõlema liigi ületunnitöö kohta nõuti ranget arvepidamist.

20. sajandi algul, kui enamikus tööstusettevõtteist lühenes tööaeg 10 tunnini päevas, suurenes märkimisväärselt ületunnitöö. 1902. aastal tehti Eestimaa kuber-

51 http://www.ilo.org/ilolex/cgi-lex/convde.pl?C047.

52 Rebane, I. Sotsiaalpoliitika ja töökaitse, 77.

53 Продолжительность рабочаго дня и заработая плата в 20 наиболее промышленных губерниях

Европейской России. СПб., 1896, 189.

54 Samas, 188.

55 Samas, 189. 
mangu vabrikutes ja tehastes 524 600, 1908. aastal 383 100, 1911. aastal 1141500 ja 1913. aastal 822700 ületundi. $^{56}$ Valdav osa - üle $70 \%, 1911$. aastal isegi 91,1\% - ületunnitööst toimus töölise ja tööandja kokkuleppel. Ületunnitöös osales suur osa vabrikutöölistest. Ajavahemikul 1902-1913 oli vabatahtliku ületunnitööga hõivatud 39-77\% vabrikutöölistest. Ühe töölise kohta tuli 1902. aastal 73 vabatahtlikku ületundi, 1908. aastal 61, 1911. aastal 111,8 ja 1913. aastal 83 ületundi. Seega suurenes, võrreldes 20. sajandi esimese kümnendi madalseisu aastatega, ületunnitöö 1911. aastal alanud tööstustõusu aastail oluliselt.

Nendesse näitajatesse tuleb suhtuda siiski teatud reservatsiooniga, sest vabrikuinspektorite kontrollaktidest nähtub, et ettevõtjad rikkusid sageli seadust: arvestust vabatahtliku ületunnitöö kohta ei peetud, sest seda rakendati ilma kubermangu vabriku- ja mäeasjade komisjoni loata. Reas ettevõtteis rakendati aga ületunnitööd lubatud mahust rohkem. Nii tehti A. Brockhauseni jahuveskis 1908. aastal üle normi 30, F. Wiegandi masinatehases 1911. aastal 10 ja 1913. aastal 56, Fr. Krulli masinatehases 1913. aastal 10 ületundi jne. ${ }^{57}$ Kõige enam rakendati ületunnitööd metallitööstuses. 1902. aastal tehti selles tööstusharus 34,4\%, 1911. aastal $39,8 \%$ ja 1913. aastal 39,2\% kõigist ületundidest. ${ }^{58}$

Kaubandus-Tööstusministeeriumi poolt kogutud andmed näitasid, et vahetult enne Esimese maailmasõja puhkemist 1914. aasta juunis pikendas ületunnitöö kehtivat 10-tunnist tööpäeva Noblessneri laevatehases 13, Vene-Balti laevatehases 11,5, Volta elektrimootoritehases 11,1, Fr. Krulli masinatehases 10,9, Dvigateli vagunitehases $10,7 \mathrm{ja} \mathrm{F}$. Wiegandi masinatehases 10,8 tunnini. ${ }^{59}$

Ületundide tegemise põhjused olid erinevates ettevõtetes erinevad. Nii tehti Balti Puuvilla Ketramise ja Kudumise Vabrikus 1907. aastal ületunnitööd selleks, et likvideerida streigi tõttu tekkinud tööseisaku tagajärjed, 1908. aastal aga seoses "kiirete tellimuste täitmisega", 1910. aastal seoses "kangrute vähesusega". Traditsiooniline oli iga-aastane ületunnitöö A. M. Lutheri mehaanilises puidutööstuses, "et kasutada päikesepaistelisi suvepäevi vineeri kuivatamiseks". 1907. aastal tehti ületunnitööd Voltas ja Dvigatelis ning 1909. aastal F. Wiegandi masinatehases seoses "kiirete, ettenägematute ning tähtajaliste tellimustega" ${ }^{60}$ Sindi kalevivabrikus rakendati 1913. aastal kolm kuud ületunnitööd seoses ettevalmistustega "Nižni-Novgorodi laadaks" jne. ${ }^{61}$

Ühelt poolt aitas ületunnitöö ettevõtjail korvata tööpäeva lühenemist ning suurendada tootmist ja andis töölistele lisateenistuse võimaluse, teiselt poolt aga suurendas tööpuudust ja seda eriti tööstuse madalseisu aastail, kui tootmist tuli

56 Arvutusalus: Сверхурочные работы в промышленных заведениях С.-Петербургского фабричного округа за 1902 год. СПб., 1904, 22-23; ЕАА, f 206, n 1, s 41, 1 1-152; s 44, 1 1-199; s 45, 1 1-243; s 46, 11-183.

57 EAA, f 206, n 1, s 41, 1246 ; s 44, 1 157; s 46, $133,61$.

58 Samas.

59 ЦГИАР, ф. 23, оп. 29, д. 101, л. 75-91, 140-165.

60 EAA, f 205, n 1, s 44, 1 2, 13, 22, 46; s 45, 1 2-3; f 209, n 1, s 41, 1 87; ЦГИАР, ф. 23, оп. 20, д. 91, л. $4,5,9,16,25,28,36$.

61 EAA, f 558, n 1, s 22, 138. 
kokku tõmmata. Nii vallandati 1906. aastal F. Wiegandi masinatehasest töö vähesuse tõttu 92 töölist, kuigi samal ajal rakendati tehases ületunnitööd. ${ }^{62}$ Töö vähesus oli tööliste vallandamise motiiviks ka Dvigateli tehases 1907. aastal, kuigi ületundide arv aasta lõpuks ulatus 16 000-ni. Samal ettekäändel jätkus tööliste vallandamine ka järgneval aastal, ületunnitöö maht aga suurenes eelmise aastaga võrreldes 2,5 korda. ${ }^{63}$

Esimese maailmasõja aastail, kui rida ettevõtteid rakendati tööle sõjaliste tellimuste täitmiseks, sisekorraeeskirjades fikseeritud tööpäeva pikkust ei muudetud, küll aga seati sisse kohustuslik ületunnitöö, mis pikendas tööaega päevas mõnes ettevõttes koguni 14 tunnini. Nii töötasid F. Wiegandi masinatehase töölised 1915. aastal iga päev 2 tundi üle normaaltööaja. Volta tehase ligi 400 töölist tegid 1916. aasta novembris ja detsembris esmaspäevast reedeni iga päev 3 ületundi, laupäevadel koguni 4-4,5 tundi. ${ }^{64}$ Tartu telefonivabrikus pikenes tööpäev ületundide arvel 10 tunnilt 12 tunnile, Leevaku linaketrusvabrikus 9 tunnilt 11 tunnile. $^{65}$ Kõige laiemas ulatuses kasutati ületunnitööd sõjavajadusteks töötavates laevatehastes, Noblessneri laevatehases tehti päevas 3, Vene-Balti ja Bekkeri laevatehases 4 ületundi. Laevatehastes kaotati ka puhkepäevad, pühapäevad loeti ületunnitööks. ${ }^{66}$

Vältimaks tööliste keeldumist ületunnitööst, nähti selleks puhuks ette suured trahvid. Nii pidi Vene-Balti laevatehase tööline maksma trahvi ületunnitööst keeldumisel: esimesel korral 50 kopikat, teisel korral 75 kopikat ning kolmandal korral 1 rubla. Neljandal korral kvalifitseeriti keelduja "riigireetjaks" ning teda ähvardas sõjakohtu alla andmine. ${ }^{67}$ Trahvidest hoolimata sagenesid koos tööpäeva ja töönädala pikenemisega töölt puudumised. 1916. aasta juulis Dvigateli tehase tööliste streigi põhjuste uurimiseks moodustatud komisjon jõudis järeldusele, et tööliste nõudmised tõsta palka ei ole põhjendatud, sest väike palk on suuresti tingitud tööluusidest. Komisjoni arvestuste kohaselt kaotati tööluusidega Dvigatelis $15 \%$, Vene-Balti laevatehases $11 \%$, Bekkeri laevatehases $10,9 \%$, Wiegandi masinatehases $9 \%$, Volta tehases $7 \%$ ja raudteetöökodades $6,1 \%$ tegelikult ettenähtud tööajast kuus. ${ }^{68}$

Ületunnitöö praktiseerimine jätkus iseseisvunud Eesti Vabariigi tööstusettevõtetes. Statistilised andmed näitavad, et ajavahemikul 1923-1928 moodustasid ületunnid 6,3-8,8\% kehtivast tööajast, nn normaaltöötundidest. 1929. aastal, kui ilmnesid ülemaailmse kriisi tunnused, vähenes järsult ületunnitöö (5\%-ni normaaltöötundidest), sest Hariduse- ja Sotsiaalministeeriumi korraldusel karmistasid tööinspektorid ületunnitöö tegemise lubade väljaandmist. ${ }^{69}$ Kuna peamised

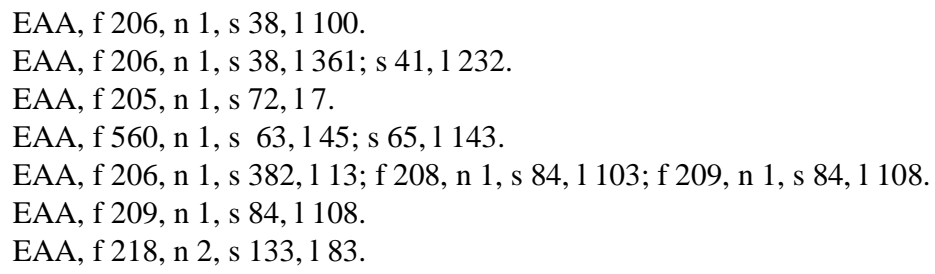

Sõrmus, R. Tööpäeva pikkus tööstuses 1929. aastal. - Eesti Statistika, 1930, 107, 533. 
ületunnitöö tegijad olid mehed, siis nende tööaeg oli 0,2 kuni 0,5 tundi naistööliste tööajast pikem.

Nagu eespool põgusalt juttu oli, piiras 1931. aasta "Tööstuslikkude käitiste tööaja seadus" vabatahtliku ületunnitöö mahu aastas ühe töölise kohta 75 tunniga, kusjuures ööpäeva jooksul oli lubatud teha kuni 2 ületundi. Vabariigi Valitsusel oli õigus keelata ületunnitöö tegemine juhul, kui see aitas tööpuudust leevendada. Erandkorras võis Sotsiaalministeeriumi töökaitse ja sotsiaalkindlustuse osakonna direktor lubada töölisel teha kuni 100 ületundi aastas. Põlevkivikaevandustel lubati erandkorras (kuni 1. oktoobrini 1932) rakendada ületunnitööd seadusega ettenähtust kolm korda suuremas mahus - 225 ületundi töölise kohta.

Kohustuslike ületundide maht jäi endiselt kindlaks määramata ning nende rakendamiseks, erinevalt vabatahtlikust ületunnitööst, polnud vaja ka tööinspektori luba. Kõigi ületundide eest tuli maksta vähemalt 50\% tavalisest kõrgemat tasu, välja arvatud kohustuslikud ületunnid, mida tehti teise töötaja asendamiseks. Ületundide kohta oli ettevõte kohustatud pidama ranget arvestust.

1935. aastaks oli majanduskriis ületatud ja ettevõtted töötasid taas täies mahus. 8 tunniga piiratud tööaeg päevas ei võimaldanud maksimaalselt kasutada tootmisvõimalusi, mida pakkus soodne majanduskonjunktuur. Seetõttu võeti jällegi appi ületunnitöö, eriti keemia-, metalli-, puidu- ja toiduainetööstuses.

Kriisiaastail tööaja kohta vastu võetud seadus hakkas kammitsema teistest enam hooajaliselt töötavate tööstusharude (turba-, savi-, tellise-, lubja- ja ehitustööstus) ettevõtteid, sest need jõudsid seadusega sätestatud normtöötundide ja ületundide jooksul täita vaid osa tellimustest. Suurema hulga tööliste palkamine oli aga takistatud töökäte puuduse pärast, mis Eestis tekkis 1936. aastal. Väljapääsu nähti seaduse muutmises. Ettevõtete taotlused kandsid vilja 1937. aastal, kui "Tööstuslikkude käitiste tööaja seaduse muutmise seadus"70 andis hooajaliselt töötavatele turba-, savikivi- ja ehitustööstustele õiguse lisaks 8-tunnisele tööajale päevas teha 1. aprillist kuni 1. oktoobrini ületunnitööd vastavalt vajadusele ilma tööinspektorilt luba taotlemata. Samuti nägi seaduse muudatus ette, et ületunnitöö võib kokkuleppel töölisega töölepingus kohustuslikuna fikseerida, et vältida hiljem tekkida võivaid arusaamatusi või ületunnitööst keeldumist.

Tööõiguse spetsialist, Tööliskoja peasekretär Ilmar Rebane kritiseeris seaduse muudatust, leides, et ületunnitöö laiendamine pole sotsiaal-poliitiliselt põhjendatud: ületundide eest makstav lisatasu ei korva kahju, mida toob tööaja muutmine piiramatuks ületunnitöö läbi. ${ }^{71}$

Eespool oli juba juttu sellest, et töölised tegid enamasti meeleldi ületunnitööd, et rohkem teenida. Probleemid tekkisid aga seoses sellega, et sageli jäeti lisatasu välja maksmata või maksti ettenähtust madalama palgatariifi alusel. 1935. aastal avastasid tööinspektorid 217 ja 1937. aastal 794 tööstuslike käitiste tööaja seaduse eeskirjade rikkumist. ${ }^{72}$ 1938. aastal tuvastasid tööinspektorid tööliste kae-

70 Riigi Teataja, 1937, 29, 277.

71 Rebane, I. Sotsiaalpoliitika ja töökaitse, 78.

72 Töökaitse Eestis 1935-1937. Tööinspektorite 1935., 1936. ja 1937. a aruannete kokkuvõte. Tallinn, 1938, 15. 
buste kontrollimise käigus 675 seaduse rikkumist. Üleastumised olid põhiliselt seotud ületunnitöö eest lisatasu maksmata jätmisega. Protokolle koostati 175 ja trahve määrati 165 korral. $^{73}$

1930. aastate lõpul taotlesid ettevõtjad vabatahtliku ületunnitöö mahu piirangu tühistamist kõigis tootmisharudes ja ületunnitöö eest maksmise aluseks oleva tariifi vähendamist poole võrra, st $50 \%$-lt $25 \%$-ni. ${ }^{74}$ Seaduslikku vormi need taotlused siiski ei võtnud. Puhkenud Teise maailmasõja tingimustes olukord tööstuses halvenes ja lisaks vallandamistele hakati kasutama majanduskriisi aastail läbiproovitud töönädala ja tööpäeva lühendamist, samal ajal tehti aga endiselt ka ületunnitööd.

\section{TÖÖLISTE PUHKEAEG}

Puhkeajad tööajal olid samavõrd vajalikud kui tööaja üldine piiramine ja selle seaduslik reguleerimine. 1860. aastail olid vaheajad suhteliselt pikad, eriti lounaajal, kestes 1-1,5 tundi, et töölised jõuaksid kodus lõunastamas käia. Lisaks oli nii hommikul kui õhtul ette nähtud 15-minutine puhkepaus. Tööpäeva lühenedes lühenesid tavaliselt ka vaheajad, sealhulgas lõunavaheaeg. Vaheajad olid fikseeritud sisekorraeeskirjades, seadusandlikult oli vaheaegade andmise kohustus reguleeritud 1882. aasta seadusega ja see puudutas vaid 12-14-aastasi vabrikutööstuses töötavaid lapsi. 8-tunnise tööaja korral tuli neile vaheaeg anda pärast 4 tundi kestnud tööd, 6-tunnise tööpäeva korral oli lubatud ka vaheajast loobuda. Siiski olid Narva Kreenholmi Puuvillamanufaktuur ja Balti Puuvilla Ketramise ja Kudumise Vabrik, kus olid ülekaalus naistöötajad, kehtestanud omaalgatuslikult emadele, kes kasvatasid alla üheaastast last, lisaks üldistele vaheaegadele kaks ühetunnist lisavaheaega päevas - hommikul kella 8.00-st kuni 9.00-ni ning pärast lõunat kella 4.00-st kuni 5.00-ni ja laupäeval üks kord kella 8.00-st kuni 9.00-ni lapse toitmiseks. ${ }^{75}$

1924. aasta seadus laste, alaealiste ja naiste töö kohta tööstusettevõtetes ${ }^{76}$ sätestas, et alaealisi kuni 18. eluaastani ei tohtinud lasta ilma vaheajata üle nelja tunni järgemööda töötada. Alles 1931. aasta tööaja korraldamise seadusega ${ }^{77}$ nähti ka üle 18-aastastele töölistele kohustuslikud töövaheajad puhkuseks ja einestamiseks. Tööstusettevõtteis, kus kehtis 8-tunnine tööpäev, tuli töölisele mitte hiljem kui pärast viiendat tundi peale töö algust anda vaheaeg, mille kestus võis olla 0,5 tunnist 1,5 tunnini. Juhul, kui tööpäev oli lühem kui 8 tundi või töötamine toimus kolmes vahetuses, polnud vaheaja andmine kohustuslik, kuid töötajal pidi olema võimalus töö ajal süüa.

\footnotetext{
73 Töökaitse Eestis 1938. Tööinspektorite 1938. a aruannete kokkuvõte. Tallinn, 1940, 13. 
Tööstusettevõtetes kehtis nende rajamisest alates iganädalane pühapäevarahu. Samuti ei tehtud tööd pühade ajal. Tsaari-Venemaal peeti vastavalt kujunenud traditsioonidele piirkonniti erinevaid pühi. Mõnes piirkonnas, kus lisaks ametlikele pühadele tähistati keisri sünnipäeva ja kroonimise ning troonileastumise päeva, tsareevitši sünnipäeva, keisrinna sünni- ning nimepäeva ja mitmeid teisi keisri perekonnaga seotud tähtpäevi, ulatus pühade arv aastas üle 20. Kreenholmi töölised, nii nagu kõik teised Eestimaa kubermangu elanikud, pidasid 19. sajandi teisel poolel järgmisi pühi: 1 . jaanuar, kolmekuningapäev, võinädala reede ja laupäev, paastumaarjapäev, suur reede ja laupäev, esimene ja teine lihavõttepüha, taevaminemise päev, nelipühade teine püha, Peeter-Pauli päev, Kristuse seletamise päev, rukkimaarjapäev, ussimaarjapäev, Maarja kaitsmise ja eestpalve päev, nigulapäev ning esimene ja teine jõulupüha. Kokku ei tehtud tööd 19 pühal.

Seadusandlikus korras sätestati esmakordselt pühapäevarahu ja riiklikud pühad ning suurte pühade eelpäevade õhtupoolikud, mil töötamine oli keelatud, 1897. aasta seadusega $^{78}$.

Vabrikuseadus nägi ette 14 püha: 1. ja 6. jaanuar, 25. märts, 6. ja 15. august, 8. september, 25. ja 26. detsember, vaikse nädala reede ja laupäev, teine ja kolmas lihavõttepüha (esimene püha langes alati pühapäevale), taevaminemispüha ja püha vaimu väljavalamise päev. 1900. aasta seadusega ${ }^{79}$ lisati veel kolm püha: 2. veebruar, 14. september ja 21. november. Seega olid töölised tööst vabastatud kõigil pühapäevadel ja vähemalt 17 pühal aastas. Mitteõiguslikele töölistele ei olnud kõik pühad kohustuslikud. Ettevõtte administratsioonil oli õigus asendada seadustes loetletud pühad sellistega, mida tähistas kohalik kirik. Eesti tööstusettevõtete sisekorraeeskirjades oli fikseeritud enamasti 18-21 luteri kiriku püha. Õigeusklike tööliste suhtes kehtis eriklausel, mille alusel vabastati nad tööst veel 3-5 õigeusupühal. Iga-aastast korralist puhkust tsaariaegne tööseadusandlus ette ei näinud.

Nii kujunes tööaasta keskmiseks pikkuseks põhilistes tootmisharudes, nagu tekstiili-, paberi-, puidu- ja metallitööstus, 292-293 päeva. Katkematu tööprotsessiga ettevõtteis oli tööperiood pikem kui mujal, sest töö katkestati vaid kaks korda kuus 12 tunniks puhastus- ja korrastustööks. Töölised töötasid neis ettevõtteis vahetusgraafiku alusel. Kõige lühem tööaasta (150-180 päeva) ja reeglina ka kõige pikem tööpäev ning rohke ületunnitöö oli sesoonselt töötavates ettevõtetes. Eestis ning kogu Balti tööstusringkonnas üldse oli tööperiood pikem nende regioonidega võrreldes, kus suurtööstus oli nõrgalt arenenud ja ettevõtted töötasid aastas keskmiselt 282-285 päeva. ${ }^{80}$ Tööaasta kujunes mõnikord lühemaks ka tööliste streikide, tellimuste puudumise, masinate remondi ja muude põhjuste tõttu.

1920. aasta aprillis seadusandliku delegatsiooni kehtestatud pühade ja puhkepäevade määruse $^{81}$ järgi olid töölised, nii nagu kõik Eesti elanikud, vabad püha-

\footnotetext{
78 Собрание узаконений и распоряжений правительства, 1897, Ст. 778.

79 ПСЗ, 1900, ХХ, Ст. 18041.

80 Arvutusalus: Данные о продолжительности рабочего времени за 1904 и 1905 года. СПб., 1906, 78-83.

81 Riigi Teataja, 1920, 67/68, 201.
} 
päevadel ja 19 riiklikul pühal: 1. jaanuar, kolmekuningapäev, iseseisvuspäev, palvepäev, suur neljapäev ja reede, ülestõusmispühad (3 päeva), 1. mai, taevaminemise püha, suvistepühad ehk nelipühad ( 3 päeva), jaanipäev, mardipäev ja jõulupühad (3 päeva). 1922. aastal asendati see määrus pühade ja puhkepäevade seadusega $^{82}$, mis vähendas pühade arvu 17-le, jättes loetelust välja suure neljapäeva ja mardipäeva, ning sätestas lühendatud tööaja suurel laupäeval, suvistepühade laupäeval, jõululaupäeval ja 31. detsembril. Neil päevadel tuli töö lõpetada kell 12 päeval. Järgmine muudatus pühade loetelus toimus alles 1934. aastal, kui riiklike pühade nimekirja võeti võidupüha (23. juuni), usupuhastuse püha (31. oktoober) ja surnutepüha ning vähendati nelipühasid 3 päevalt 2-le. Lühendatud tööajaga päevade (töö lõppes kell 12 päeval) nimekirja lisati võidupüha laupäev (22. juuni). ${ }^{83}$ Nii tõusis riiklike pühade arv taas 19-le.

1925. aastal kehtestati tööstusettevõtete nädala puhkepäevade seadus ${ }^{84}$, täites Rahvusvahelise Tööorganisatsiooni vastavat konventsiooni ${ }^{85}$, millega Eesti oli ühinenud 2. novembril 1923. Seaduse kolmanda paragrahvi järgi vabastati töölised tööstusettevõtteis tööst pühapäevadeks vähemalt 36 tunniks ja riiklikeks pühadeks vähemalt 24 tunniks järgemööda. Erandkorras oli töö pühapäevadel ja pühadel lubatud: ühiskonna huvides elanike igapäevaste tarviduste rahuldamiseks tehtavail töödel; tööstuse tehnilise iseloomu tõttu katkematu tööprotsessiga töödel; teatud valvetöödel; kiiresti riknevate toorainete või toiduainete töötlemisega seotud töödel. Kui need tööd kestsid pühapäeviti või pühade ajal üle nelja tunni, siis tuli anda töölisele puhkepäev mõnel teisel päeval või kompenseerida rahaliselt kui ületunnitöö, mis tähendas kehtestatud palgatariifidest $50 \%$ suuremat tasu. ${ }^{86}$ 14- ja 15-aastaste töötamine pühapäevadel ja pühadel oli keelatud. 1936. aasta 17. juuni tööstusettevõtete nädala puhkepäevade seaduse muutmise seadus ${ }^{87}$ tegi erandi ajalehtede ilmumisega seotud trükikodadele, lubades töölised vabastada nii pühapäevadeks kui riiklikeks pühadeks järjestikku 24 tunniks. Nii kärbiti trükitööliste puhkeaega pühapäevadeks 12 tunni võrra.

Ometi ei kasutanud töölised maksimaalselt neile antud võimalust puhata. 1929. aastal avaldatud artiklis märkis R. Sõrmus, et töölised jätavad massiliselt kasutamata õigused, mida neile kindlustab nädala puhkeaja seadus, ja töötavad järjest 7 päeva nädalas. Tema arvates oli madal töötasu põhjuseks, miks töölised, eelkõige mehed, eelistasid puhkusele rahalist kompensatsiooni. ${ }^{88}$

1930. aastail ilmus Eesti tööõigusesse selline uus mõiste nagu palgaline puhkus. Palgalise puhkuse õigust oli tunnustatud Austrias osaliselt juba 1910. aastal, mõnes riigis aga pärast Esimest maailmasõda ja laiemas ulatuses alles 1930. aastail. Eesti naaberriikides Soomes ja Lätis oli palgaline puhkus kehtestatud juba

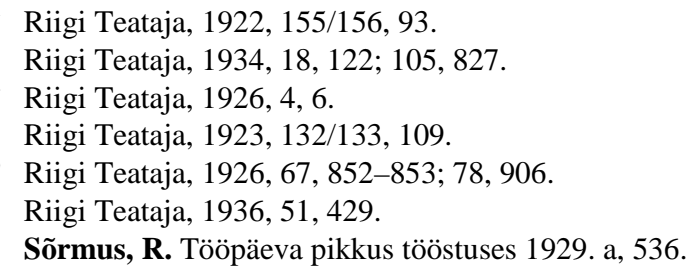


1922. aastal. ${ }^{89}$ 1937. aastal kehtis palgaline puhkus kõigile töötajaile 22 riigis ja mõnele töötajate kategooriale 16 riigis. Keskmiseks puhkeaja pikkuseks oli 12 tööpäeva. Palgalise puhkuse õigus tekkis enamasti pärast aastast töötamist. Nii oli see Taanis, Itaalias, Lätis, Leedus, Norras, Poolas, Prantsusmaal, Rootsis, Saksamaal ja mujal. Inglismaal oli puhkus reguleeritud kollektiivlepingutega ${ }^{90}$ Riigid tunnustasid palgalise puhkuse vajadust mitmel põhjusel. Ratsionaliseerimisega koos oli kasvanud töö monotoonsus ja pinge, suurenenud tööliste närvilisus. Üldine kultuuritaseme tõus oli suurendanud tööliste kultuurivajadust. Ka majanduse seisukohalt oli palgaline puhkus tulus: puhkuseajal kulutasid inimesed rohkem kui tavaliselt ning selle tulemusena kiirenes raharinge ja elavnes majandus.

1934. aasta 21. detsembri tööstustööliste palgalise puhkeaja seaduse ${ }^{91}$ kohaselt tuli ettevõtete valdajail võimaldada igal aastal seitsmepäevane tasuline puhkus töölistele, kes olid ettevõttes töötanud vähemalt aasta. Juhul, kui ettevõtte omanikul tekkis raskusi anda seitse päeva järjest kestvat puhkust, võis ta seaduse järgi sellest kohustusest vabaneda tööliste suhtes, kellele ta maksis tasu kolme jõulupüha, uusaasta, iseseisvuspäeva, suure reede ja esimese ülestõusmispüha eest, kusjuures tööline pidi olema nimetatud pühadel tööst vaba.

Just puhkuse asendamise võimalust rahalise kompensatsiooniga luges Tööliskoja peasekretär Ilmar Rebane seaduse suureks puuduseks. Ta heitis seadusele ette ka puhkuse andmise võimalust talvel ning et reguleerimisalast olid välja jäetud ehitustöölised. Seetõttu pidas ta oluliseks töölisorganisatsioonide võitlust nende puuduste kõrvaldamiseks ja palgalise puhkuse pikendamiseks vähemalt 12 tööpäevale. $^{92}$

Vähesed säilinud arhiivimaterjalid näitavad siiski, et üldiselt praktiseeriti kollektiivset puhkust suvel. Nii näiteks algas Kreenholmi Manufaktuuri tööliste puhkus aastail 1935-1940 reeglina enne jaanipäeva, sest siis oli võimalik liita puhkusele selle pikendamiseks kaks riiklikku püha - võidupäeva ja jaanipäeva. ${ }^{93}$

Ametiühingute visa nõudmine 12-päevase palgalise puhkuse kehtestamiseks sundis valitsust välja töötama sellekohast seadusprojekti, mis sai töösturite terava kriitika osaliseks. Töösturite seisukohta väljendas Kaubandus-Tööstuskoja Teatajas 1937. aastal avaldatud artikkel "Palgaline puhkeaeg. Kas oleme õigustatud teistest maadest üle pakkuma?"94. Selles avaldati arvamust, et Eesti sotsiaalseadused ei ole tegelikult Eestile jõukohased. Tasulise puhkuse pikendamisel ei saa lähtuda ainult hetkeseisust, st majanduse kõrgseisust, vaid tuleb vaadata tulevikku. Samuti heideti ette teiste riikide, eriti rikaste tööstusriikide sotsiaalseaduste kopeerimist. Artiklis juhiti tähelepanu sellele, et palgalise puhkeaja suurendamisega väheneb tootmisprotsessiks vajalike tööpäevade arv aastas, mis Eestis on pühade, pühade-

89 ERA, f 969, n 6, s 71, 15.

90 Rebane, I. Sotsiaalpoliitika ja töökaitse. Tartu, 1939, 83.

91 Riigi Teataja, 1934, 108, 848.

92 Rebane, I. Sotsiaalpoliitika ja töökaitse, 84.

93 ERA, f 2113, n 1, s 372, 1 408; f 2117, n 1, s 81, 178; Põhja Kodu, 1940, 12. juuni.

94 Sks. Palgaline puhkeaeg. Kas oleme õigustatud teistest maadest üle pakkuma? - KaubandusTööstuskoja Teataja, 1937, 4, 87-88. 
eelsete poolikute päevade, hiljaksjäämiste ja haiguspäevade tõttu niigi väike (keskmiselt 286-290 päeva aastas). Teiselt poolt nõuab täiendavate puhkusepäevade andmine lisakulutusi ligi 900000 krooni ulatuses, mis on tööstusele finantsiliselt koormav. Nii üks kui teine tegur ohustab riigi majanduslikku kandevõimet.

Kui 1940. aasta märtsis algas parlamendis tööliste puhkeaja seaduse arutelu, ütlesid töösturid selgelt välja oma seisukoha: nad ei toeta tööaja lühendamist tööstuses palgalise puhkeaja pikendamisega, sest Eesti majanduslikud olud ei võimalda lühikese tööajaga tagada kodanikele rikkalikku toidulauda, korralikku peavarju ja ihukatet, head haridust, vaimsete vajaduste rahuldamist ja muid elumõnusid. Vastupidi, seoses halvenenud turukonjunktuuriga pidasid nad vajalikuks rohkem ja intensiivsemalt tööd teha, et vältida rahva elatustaseme langust ning toota küllaldasel määral kaupa väiksemate tootmiskulude ja madalamate hindadega. Nad soovitasid seaduse vastuvõtmise rahulikumale ja paremale ajale edasi lükata. ${ }^{95}$

Tööliste palgalise puhkeaja seadus ${ }^{96}$, mille koostamisel võeti eeskujuks nii naabermaade seadused tööliste puhkuse alal kui ka Rahvusvahelise Tööorganisatsiooni 1936. aasta tasulise puhkuse konventsioon, kiideti parlamendis heaks ja 1940. aasta aprillis kuulutas president selle seaduse välja. Seaduse järgi oli õigus saada palgalist puhkust kõigil töölistel (välja arvatud hooajatöölised ${ }^{97}$ ), kelle kohta kehtis 1. jaanuarist 1937 jõustunud tööliste töölepingu seadus ${ }^{98}$. Kui 1934. aasta seadus nägi ette ühesuguse pikkusega puhkuse, seadis uus seadus puhkuse kestuse sõltuvusse töölise pidevast tööstaažist ettevõttes: 1-2-aastase tööstaažiga töölisel oli õigus saada puhkust 1 nädal, 3-6-aastase staažiga 9 tööpäeva ja alates 7-aastasest tööstaažist kaks nädalat. Tasu maksti vaid tööpäevade eest. Alla 18-aastastele alaealistele tuli puhkust anda pärast aastast töötamist kaks nädalat. Puhkust pidi tööandja võimaldama töölistele ajavahemikul 1. aprillist 1. novembrini. Juhul kui töölisele ei olnud võimalik anda ettenähtud puhkust, tuli saamata jäänud puhkusepäevade eest maksta rahalist kompensatsiooni 1,5-kordse töötasu ulatuses.

Seaduse elluviimisega astus Eesti suure sammu edasi, ühtlustamaks oma sotsiaalpoliitikat rahvusvaheliselt tunnustatud sotsiaalpoliitikaga.

\section{KOKKUVÕTE}

Ajavahemikul 1870-1940, kapitalistliku tööstuse rajamise ja arengu aastail Eestis, toimusid kiired muutused kogu ühiskonnas, sealhulgas koos tööstusega tekkinud uue sotsiaalse kihi - palgatööliste sotsiaal-majanduslikus olukorras. Kapita-

95 Palgalise puhkeaja pikendamine. - Kaubandus-Tööstuskoja Teataja, 1940, 4, 103-104.

96 Riigi Teataja, 1940, 33, 252.

97 Nende väljajätmist puhkusesaajate ringist põhjendati sellega, et hooajatöölised puhkavad tööde vaheaegadel nagunii. Seejuures unustati, et ilma rahata, ja seetõttu seadis seadus hooajatöölised teiste töölistega võrreldes halvemasse olukorda.

98 Vt Riigi Teataja, 1936, 83, 663. 
lismi arengu varasel perioodil oli tööjõu üleküllus, ning kuna vabrikud ja tehased vajasid vähe tööjõudu, sai palgatud töölistele karmide töötingimuste kehtestamisega suure kasumi saamise eesmärgil tugevat survet avaldada. Tööturu üleküllusele vaatamata kasutati ohtralt füüsiliselt nõrkade - laste ja naiste tööjõudu. Töökaitsealased õigusaktid puudusid, seetõttu ei saanud rääkida ka ohututest ja tervislikest töötingimustest. Töötingimused sõltusid täiesti vabrikantide tahtest. Ettevõtetes valitses range distsipliin, tööpäev oli pikk ja kestis kõigile kuni 16 tundi päevas, palk oli väike. Lääneriikide eeskuju sundis tsaarivalitsust alustama töötingimuste parandamist kõige nõrgematest. 1882.-1885. aasta seadustega seati laste töö kasutamisele tööstuses vanuseline piirang ja lühendati alaealiste tööaega, samuti keelati alaealiste ja naiste öötöö tekstiilitööstuses, kus nende tööjõudu kasutati kõige rohkem. Lääneriikide eeskuju, vabrikantide enda tootmisalase teadlikkuse kasv ja töölisliikumise surve olid need kolm põhitegurit, mis tingisid 1897. aastal seadusandlikus korras Venemaa kõigi vabrikutööliste töö- ja puhkeaja normeerimise. Tööliste revolutsioonilise võitluse tulemusena saavutati 20. sajandi algul tööpäeva lühenemine 11,5 tunnilt 10 tunnini, 1917. aasta kevadel 8 tunnini pävas. Seadusandlus jäi tegelikust elust kaugele maha. Eesti Vabariigis seadustati 8-tunnine tööpäev alles 1931. aastal.

Kuigi iseseisvunud Eestis rakendati kahe maailmasõja vahel tsaariaegset seadusandlikku baasi, astuti samme sotsiaalsfääri moderniseerimiseks ning seadusandluse ühtlustamiseks rahvusvaheliselt tunnustatud tööõiguse normidega. Seda tingis vajadus tagada töölistele töö- ja elustandardi miinimum, sest see oli Esimese maailmasõja aastail langenud. Teisalt tuli tööliste töötingimusi parandada ja nende nõudmisi täita, et vältida sotsiaalseid rahutusi ja tagada ühiskonna stabiilsus. Eesti valitsus arvestas küll rahvusvahelist kogemust ja suundi sotsiaalpoliitikas, kuid ei olnud väga kiire ja aldis neid rakendama, välja arvatud alaealiste ja naiste tööd käsitlevad õigusnormid. Üks põhjusi oli see, et Eesti ei saanud ühepoolselt rakendatud sotsiaalseadustega ennast konkurentidega võrreldes ebasoodsamasse olukorda asetada. Eesti majandusnäitajad, eriti konkurentsivõime maailmaturul, jäid alla nii mõnelegi naaberriigile, rääkimata suurtest tööstusriikidest. Nii tööaja lühendamisega kui 1934. aastal nädalase, 1940. aastal aga kuni 12-päevase tasulise puhkuse sisseseadmisega seotud kulud tuli ettevõtjatel endil kanda ja see suurendas püsikulude osatähtsust tootmiskuludes. Teisalt aga teadvustati töötingimuste parandamise positiivset mõju tootmisele.

8-tunnine tööpäev, ületunnitöö piiramine, samuti palgalise puhkuse sisseseadmine andis töölistele paremad võimalused oma töövõime taastamiseks, pereringis viibimiseks, vaimsete ja kultuuriliste vajaduste rahuldamiseks, osalemiseks kultuuriüritustel ja eneseharimiseks. Kõik see mõjutas positiivselt töö kvaliteeti ja tööviljakuse kasvu, mis omakorda võimaldas ühiskonnal muutuda jõukamaks ja investeerida sotsiaalsfääri. 


\section{EESTI TÖÖSTUSTÖÖLISTE TÖÖ- JA PUHKEAEGA KÄSITLEVAD TÄHTSAMAD ÕIGUSAKTID}

Закон 1 июня 1882 г. «О малолетних, работающих на заводах, фабриках и мануфактурах». - Полное Собрание Законов (ПСЗ) Российской империи. T. II. 1882. Ст. 931.

Закон 12 июня 1884 г. «О школьном обучении малолетних, работающих на заводах, фабриках и мануфактурах, о продолжительности их работы и о фабричной инспекции». - ПСЗ. T. IV. 1884. Ст. 2316.

Закон 3 июня 1885 г. «О воспрещении ночной работы несовершеннолетним и женщинам на фабриках, заводах, и мануфактурах». - ПСЗ. Т. V. 1885. Ст. 3013.

Закон 24 апреля 1890 г. «Об изменении постановлении о работе малолетних, подростков и лиц женского пола на фабриках, заводах, и мануфактурах и о распространений правил о работе и обучении малолетних на ремесленныя заведения». - ПСЗ. Т. Х. 1890. Ст. 6742.

Закон 2 июня 1897 г. «О продолжительности и распределений рабочего времени в заведениях фабрично-заводской промышленности». - Собрание узаконений и распоряжений правительства. 1897. Ст. 778.

Закон 22 января 1900 г. «О дополнении расписания праздничных дней, в которые не полагается работы в заведениях фабрично-заводской и горной промышленности». - ПСЗ. 1900. ХХ. Ст. 18041.

Устав о промышленном труде $\S$ 64-70, 73-76, 193-201. - Свод законов Российской империи. 1913. Т. ХІ, ч. 2.

Декрет 29 октября 1917 г. «О 8-часовом рабочем дне». - Собрание узаконений и распоряжений рабочего и крестянского правительства. 1917. № 1, Ст. 10.

27. aprilli 1920. a seadusandliku delegatsiooni määrus pühade ja puhkepäevade kohta. - Riigi Teataja (RT), 1920, 67/68, 201.

7. detsembri 1922. a seadus pühade ja puhkepäevade kohta. - RT, 1922, 155/156, 93.

20. mai 1924. a seadus laste, alaealiste ja naiste töö kohta tööstusettevõtetes. RT, 1924, 68, 30.

17. detsembri 1925. a seadus tööstusettevõtete nädala puhkepäevade kohta. RT, 1926, 4, 6. 
Töö-hoolekandeministri 23. oktoobri 1926. a määrus puhke ja tasu võimaldamise korra kohta isikutele, kes seotud töödega, mille täitmine lubatud pühapäevadel ja pühadel tööstusettevõtete nädala puhkepäevade seaduse $\S 4$ põhjal. - RT 1926, 78, 906.

10. juuli 1931. a seadus tööstuslikkude käitiste tööaja kohta. - RT 1931, 61, 487.

26. veebruari 1934. a seadus pühade ja puhkepäevade kohta. - RT 1934, 18, 122.

14. detsembri 1934. a seadus pühade ja puhkepäevade kohta. - RT 1934, 105, 827.

21. detsembri 1934. a seadus tööstustööliste palgalise puhkeaja ja töölepingu lõpetamiseks tarviliku ülesütlemise aja pikendamise kohta. - RT 1934, 108, 848.

17. juuni 1936. a seadus tööstusettevõtete nädala puhkepäevade seaduse muutmise kohta. - RT 1936, 51, 429.

9. aprilli 1937. a seadus tööstuslikkude käitiste tööaja seaduse muutmise kohta. RT 1937, 29, 277.

15. aprilli 1940. a seadus tööliste palgalise puhkeaja kohta. - RT 1940, 33, 252.

\section{HOURS OF WORK AND HOLIDAYS IN ESTONIAN INDUSTRIES AND THE RELEVANT LEGISLATION, 1870-1940}

\section{Maie PIHLAMÄGI}

As mechanised industry required few skills, there was an abundance of work force. In the 1860s and 1870s, the wages remained low and the working day lasted 14-16 hours. There was no insurance against accident, sickness or old age. The absence of social reforms led to various protests by workers. The main way through which the workers protested against the injustice of the employers and improved their status was striking movement. While the workers were helping themselves, the government also did its share through legislation. As government officials were well informed about the relevant laws in the leading industrial countries, the first factory act, passed in June 1882, forbade the employment of children under 12, limited the working hours of teenagers between 12 and 15 to eight hours and abolished the night work for them. By the act of 1897, the working day for labour over 15 years of age was reduced to 11 and a half hours on ordinary days and 10 hours on Saturdays and eves of calendar holidays. Overtime work became legal and was limited to 120 hours per worker annually. As a result of the revolutionary movement, the working day in the industrial enterprises was set at ten hours in 1905 and at eight hours (48 hours per week) in 
March 1917. It was only in 1931 that the eight-hour working day was made legal and overtime work was limited to 75 hours per worker annually.

The act of 1897 instituted Sundays as days free of work and 14 statutory calendar holidays. In 1900, another three holidays were added. Since 1920, the workers enjoyed days free of work on Sundays and 19 statutory general holidays. No money was paid for the free days. Following the recommendation of the International Labour Organisation, in 1935 an annual paid holiday of at least six working days after one year of continuous service was established for Estonian industrial workers. In 1940, workers who had three or seven years of continuous service were entitled to annual paid holiday of at least nine and twelve working days, respectively.

Thanks to the reduction of working hours and establishment of annual paid holidays the workers had more time and opportunities to take part in cultural life, to raise their educational level and spend more time with the family. The reduction of the working time contributed to improving the workers' health and to increasing labour productivity. 